\title{
Federal Preemption, Removal Jurisdiction, and the Well-Pleaded Complaint Rule
}

Plaintiff sues defendant in state court, relying solely on state law. Defendant removes the action to federal district court pursuant to 28 U.S.C. $\$ 1441$. $^{1}$ As grounds for removal, defendant alleges that Congress has preempted the state law on which plaintiff relies, so that the only law under which plaintiff can possibly state a claim for relief is federal, and that the action therefore "arises under" federal law. ${ }^{2}$ Plaintiff moves to remand the case, arguing that the district court lacks jurisdiction because the complaint does not by its terms invoke federal law. This hypothetical case raises an important and difficult question as to the interpretation of the "well-pleaded complaint rule," which limits the original federal question jurisdiction of the federal courts. ${ }^{3}$ Under the wellpleaded complaint rule, neither a federal defense nor the plaintiff's anticipation of a federal defense in his complaint suffices to vest original jurisdiction in a federal court. ${ }^{4}$ Arguing that federal preemption is merely a defense, the plaintiff in this hypothetical case might contend that removal is barred, since section 1441 limits removal to cases in which the federal district court would have had original jurisdiction. ${ }^{5}$ Since federal preemption is raised by the defendant in this case, the well-pleaded complaint rule would appear to require that the district court remand the action to state court.

The federal courts have long struggled over whether, and under what circumstances, removal could be based on a defendant's allegations of federal preemption. In Franchise Tax Board

128 U.S.C. \& 1441 (1982).

2 The Constitution extends federal jurisdiction to cases and controversies "arising under this Constitution, the Laws of the United States, and Treaties made, or which shall be made, under their authority." U.S. ConsT. art. III, § 2, cl. 1. Original jurisdiction in the federal district courts over civil actions "arising under the Constitution, laws, or treaties of the United States" is conferred by statute. 28 U.S.C. $\$ 1331$ (1982). In this comment the former will be referred to as constitutional federal question jurisdiction, the latter as statutory federal question jurisdiction. For further discussion of the differences between the two, see infra notes 9-47 and accompanying text.

3 See, e.g., Franchise Tax Bd. v. Construction Laborers Vacation Trust, 103 S. Ct. 2841 (1983); Phillips Petroleum Co. v. Texaco, 415 U.S. 125 (1974); Gully v. First Nat'l Bank, 299 U.S. 109 (1936); Louisville \& N.R.R. v. Mottley, 211 U.S. 149 (1908).

See cases cited supra note 3 ; infra notes 9-47 and accompanying text.

- 28 U.S.C. § 1441(a) (1976). 
v. Construction Laborers Vacation Trust, ${ }^{6}$ the Supreme Court for the first time directly addressed the preemption removal problem. ${ }^{7}$ It indicated that removal is proper if "a federal cause of action completely preempts a state cause of action [because] any complaint that comes within the scope of the federal cause of action necessarily 'arises under' federal law."

Although Franchise Tax Board recognized that preemption removal is proper in some instances, the Court failed to explain how preemption removal fits into the overall framework of original federal jurisdiction and the well-pleaded complaint rule. Since the relationship between federal preemption and a plaintiff's cause of action is frequently quite complex, the ambiguities of Franchise Tax Board may render its application to future cases difficult. In addition, the Court failed to discuss approaches to the preemption removal problem that had previously been taken by lower courts. As a result, the continuing validity of the "artful pleading doctrine," which permits removal where the plaintiff has manipulated his complaint to avoid presenting a federal question, is left unclear. Nor does Franchise Tax Board resolve whether preemption removal is ever proper when the preempting federal law does not create a superseding cause of action.

This comment seeks to answer these questions by exploring the implications of Franchise Tax Board for the interpretation of the well-pleaded complaint rule. Part I considers the well-pleaded complaint rule's history and purposes, and reveals a recurrent ambiguity in the Court's pronouncements as to whether the rule requires that a federal question be presented by the language of the complaint or whether a court can look beyond the face of the complaint to ascertain the underlying nature of the plaintiff's cause of action. Part II presents the approaches to preemption removal taken prior to Franchise Tax Board, and concludes that the lower courts' difficulties with the preemption removal problem reflect the tension created by the ambiguity in the well-pleaded complaint rule. Finally, Part III examines Franchise Tax Board's resolution of this tension. It suggests that the decision is consistent with an interpretation of the rule that focuses on the plaintiff's underlying

- 103 S. Ct. 2841 (1983).

7 The Court appeared to approve of preemption removal in Avco Corp. v. Aero Lodge No. 735, 390 U.S. 557 (1968), aff'g 376 F.2d 337 (6th Cir. 1967). Although the Franchise Tax Board Court treated Avco as if it had settled the question, $103 \mathrm{~S}$. Ct. at 2853-54, the Court's opinion in Avco itself is less explicit. See infra notes 60-64 and accompanying text.

103 S. Ct. at 2854. 
cause of action, and considers the implications of that interpretation for the artful pleading doctrine and the requirement that preemption jurisdiction be based on a superseding federal cause of action.

\section{The Well-Pleaded Complaint Rule}

The Constitution provides that the judicial power of the United States shall extend to all cases "arising under this Constitution, the Laws of the United States, and Treaties made, or which shall be made, under their authority." This "federal question" jurisdiction helps to insure uniformity in the construction and interpretation of federal law, and provides a federal forum for the vindication of federally created rights in the face of potential statecourt hostility. ${ }^{10}$ For most of the nineteenth century, Congress apparently felt that appellate review by federal courts of federal issues decided by state courts adequately served these purposes; ${ }^{11}$ the first permanent grant of original federal question jurisdiction was not enacted until the Judiciary Act of $1875 .^{12}$

Although Congress couched its grant of original federal question jurisdiction in language identical to that found in article III, 13 this statutory language has been construed more narrowly than its

- U.S. Const. art. III, § 2, cl. 1.

${ }^{10}$ See Martin v. Hunter's Lessee, 14 U.S. (1 Wheat.) 304, 347 (1816) (Story, J.); AMERIcan Law Institute, Study of the Division of JuRisdiction Between State and Federal Cour's 164-68 (1969); D. CurrIE, Federal Courts 160 (3d ed. 1982); Hornstein, Federalism, Judicial Power and the "Arising Under" Jurisdiction of the Federal Courts: A Hierarchical Analysis, 56 IND. L.J. 563, 564-65 (1981).

An additional purpose for original federal question jurisdiction is to establish a body of courts with special expertise in construing federal law. Further, given the impossibility of Supreme Court review under 28 U.S.C. $\$ 1257$ (1976) of all state court decisions of federal law due to the magnitude of the Court's current case load, original federal question jurisdiction provides many litigants with their only real opportunity to obtain a federal forum to decide their federal claims. See D. CurRIE, supra, at 160. Finally, appellate review may not always be sufficient to vindicate federally created rights because, as fact-finder, a state court retains substantial capacity to control the shape and outcome of litigation. See England v. Louisiana State Bd. of Medical Examiners, 375 U.S. 411, 416-17 (1964).

12 Such review was provided for in $\S 25$ of the Judiciary Act of 1789. See Judiciary Act of 1789 , ch. $20, \S 25,1$ Stat. 73,85 (current version at 28 U.S.C. $\$ 1257$ (1982)). The Judiciary Act of 1789 created inferior federal courts, see id. $\$ \S 2-4$, with original jurisdiction over diversity suits, suits in admiralty, and a few other kinds of cases, see id. $\$ \S 9,11$. It did not grant original federal question jurisdiction to the federal courts.

12 Judiciary Act of 1875 , ch. $137, \S 1,18$ Stat. 470,470 (current version at 28 U.S.C. $\S$ 1331 (1982)). Congress granted original federal question jurisdiction briefly in the Midnight Judges Act, ch. 4, § 11, 2 Stat. 89 (1801), which was repealed in 1802, Act of Mar. 8, 1802, ch. 8, § 1, 2 Stat. 132, 132; see Hornstein, supra note 10, at 565 n.8.

13 Judiciary Act of 1875 , ch. $137, \S 1,18$ Stat. 470,470 (current version at 28 U.S.C. $\S$ 1331 (1982)). 
constitutional counterpart by the application to it of the wellpleaded complaint rule. ${ }^{14}$ Under the well-pleaded complaint rule, jurisdiction may not be based on a plaintiff's anticipation in his complaint of a federal defense or a federal response to a possible defense. ${ }^{15}$ The rule is carried over to the removal context by virtue of 28 U.S.C. $\S 1441$, which limits removal to cases over which federal district courts would have had original jurisdiction. ${ }^{16}$

${ }^{14}$ For a long time, there was considerable doubt whether the well-pleaded complaint rule was a constitutional as well as a statutory limitation on federal question jurisdiction. There is language in Osborn v. Bank of the United States, 22 U.S. (9 Wheat.) 738 (1824) (Marshall, C.J.), the preeminent early case construing the scope of constitutional federal question jurisdiction, that might be read to imply a constitutional well-pleaded complaint rule: "[W]hen a question to which the judicial power of the Union is extended by the constitution, forms an ingredient of the original cause, it is within the power of Congress to give ... jurisdiction of that cause, although other questions of fact or law may be involved in it." Id. at 823 (emphasis added). Judge Friendly apparently reads Osborn this way. See T.B. Harms Co. v. Eliscu, 339 F.2d 823, 825 (2d Cir. 1964) (Osborn extends the constitutional limits of original federal question jurisdiction "to every case in which federal law furnished a necessary ingredient of the claim." (emphasis added)). Other language in Osborn, however, would tend to suggest that this reference to the original cause is not intended to limit the constitutional reach of original jurisdiction. For example, Chief Justice Marshall also stated that original federal question jurisdiction could be conferred over any case to which appellate jurisdiction extends, see Osborn, 22 U.S. (9 Wheat.) at 820-21, which, given the constitutionality of appellate federal question jurisdiction over federal defenses, see Martin $\mathrm{v}$. Hunter's Lessee, 14 U.S. (1 Wheat.) 304 (1816); see also Osborn, 22 U.S. (9 Wheat.) at 824 ("The questions which the case involves, then, must determine its character, whether those questions be made in the cause or not."), implies that original jurisdiction could be conferred over cases involving federal defenses.

Osborn has not, in fact, generally been read to impose the well-pleaded complaint rule as a constitutional requirement. See, e.g., Textile Workers Union v. Lincoln Mills, 353 U.S. 448,471 (1957)(Frankfurter, J., dissenting)("traditional interpretation" of Osborn and other cases is that jurisdiction may be extended to any case involving "potential federal questions"); Hornstein, supra note 10, at 576. Recently, the Supreme Court settled the dispute, locating the source of the well-pleaded complaint rule in the statutory grant of jurisdiction, 28 U.S.C. $\$ 1331$ (1982), and not in the Constitution. Verlinden B.V. v. Central Bank, 103 S. Ct. 1962, 1972 (1983) (upholding 28 U.S.C. $\$ 1330$, which provides for original jurisdiction in federal court over cases involving foreign sovereigns or their representatives, despite the fact the plaintiff's claim for relief did not depend on any issue of federal law). For further discussion of Verlinden and the constitutional implications of the well-pleaded complaint rule, see infra notes 22,25 and accompanying text.

1s See Louisville \& N.R.R. v. Mottley, 211 U.S. 149 (1908). For further discussion of Mottley, see infra notes 17-20 and accompanying text.

1828 U.S.C. \& 1441 (a) (1982). Under early versions of the removal statute federal defense removal was routinely granted. E.g., Pacific Railroad Removal Cases, 115 U.S. 1 (1888) (construing the removal provision of the Judiciary Act of 1875, ch. 137, § 2, 18 Stat. 470, 470 (amended 1887)). In Tennessee v. Union \& Planters Bank, 152 U.S. 454 (1894), the Supreme Court construed removal under the Act of March 3, 1887, ch. 373, § 1, 24 Stat. 552, 552 (amending Judiciary Act of 1875, ch. 137, 18 Stat. 470). Relying on language recently added to the statute, which provided for removal of cases "arising under [federal law] of which the . . . courts of the United States are given original jurisdiction," $i d$. (emphasis added), the Court held that a federal matter raised as a defense to a state-law claim could not form the 
The case most frequently cited in support of the well-pleaded complaint rule is Louisville \& Nashville Railroad v. Mottley. ${ }^{17}$ Mottley, the plaintiff, alleged in her complaint that a federal statute on which the railroad was expected to rely in defense was unconstitutional, and sought to use this allegation as the basis for federal question jurisdiction. Although the validity of the railroad's defense had been litigated below, the Court raised the jurisdictional defect sua sponte, holding that "a suit arises under the Constitution and laws of the United States only when the plaintiff's statement of his own cause of action shows that it is based upon those laws or that Constitution."18 Consequently, the Court concluded, " 'a suggestion of one party, that the other will or may set up a claim under the Constitution or laws of the United States, does not make the suit one arising under that Constitution or those laws' ";19 the Court dismissed the suit for want of jurisdiction. The Court did not explain or justify its holding, but simply declared it to be a "settled interpretation," citing a number of cases in support of the rule. ${ }^{20}$

Although it has been the target of substantial criticism, particularly as applied in the removal context, ${ }^{21}$ and despite its long history, the rationale of the well-pleaded complaint rule has seldom been thoroughly analyzed. It is clear, however, that the wellpleaded complaint rule serves an important purpose in the scheme of federal jurisdiction by limiting the reach of original federal

basis for removal. 152 U.S. at 461-62. Although the statutory language relied on by the Court appears to compel application of the well-pleaded complaint rule to removal, an alternative interpretation has been offered suggesting that the language merely refers to and incorporates the requirement of a minimum amount in controversy for original jurisdiction. See Hornstein, supra note 10, at $606 \mathrm{n} .234$. This alternative interpretation could not apply to the current removal statute, 28 U.S.C. $\$ 1441$ (a) (1982), because there is no longer a requirement of an amount in controversy for original federal question jurisdiction. See Federal Question Jurisdictional Amendments Act of 1980, Pub. L. No. 96-486, § 2(a), 94 Stat. 2369,2369 (amending 28 U.S.C. § 1331 (1976) so as to repeal amount-in-controversy requirement of statutory original federal question jurisdiction).

27211 U.S. 149 (1908).

18 Id. at 152.

19 Id. at 153 (quoting Tennessee v. Union \& Planters Bank, 152 U.S. 454, 464 (1894)).

${ }^{20}$ Id. at 152; see id. at 154 (string-citing 18 Supreme Court cases in support of the rule).

${ }^{21}$ See, e.g., American LAw InstituTE, supra note 10, § 1311 (proposing a rule allowing federal defense removal where the amount in controversy exceeds $\$ 10,000$ ); Hornstein, supra note 10, at 608 (proposing general federal defense removal); Wechsler, Federal Jurisdiction and the Revision of the Judicial Code, 13 LAw \& ConTEMP. Prons. 216, 233-34 (1948). But see H. Friendly, supra note 10, at 124 (arguing that federal defense removal would overburden federal courts). A thorough discussion of the desirability of federal defense removal is beyond the scope of this comment. 
question jurisdiction. In contrast to appellate jurisdiction, where the questions before the court are fixed by the decision below and by the questions presented on appeal, it is unclear at the time a court exercises original jurisdiction precisely which issues will arise during the course of the litigation. ${ }^{22}$ A federal question might be raised during the course of virtually any litigation. ${ }^{23}$ Thus, to base original federal question jurisdiction on the existence of merely potential federal questions in a case would render illusory the limitation of federal jurisdiction in article III to specifically enumerated classes of cases. The well-pleaded complaint rule avoids this consequence.

To say that the well-pleaded complaint rule is designed to limit original federal question jurisdiction, however, does not, without more, justify it. The well-pleaded complaint rule withdraws from original federal jurisdiction a large number of cases that eventually do turn on the validity of a federal defense, and such cases are within the purposes of federal question jurisdiction. ${ }^{24}$ One is therefore required to articulate a rationale for the particular limit placed on federal jurisdiction by the well-pleaded complaint rule.

The well-pleaded complaint rule does solve one obvious problem with predicating original jurisdiction on a federal defense: that the defense may never be raised. The proposition that a case arises under a law that is never raised during the entire course of an action seems untenable. ${ }^{25}$ Since, however, in the removal context the

22 See Hornstein, supra note 10 , at 605.

23 The existence of a potential federal question in virtually every litigation is apparent insofar as the existence of federal jurisdiction is itself a federal question and, more importantly, insofar as every state law or procedural rule may be constitutionally challenged. Osborn v. Bank of the United States, 22 U.S. (9 Wheat.) 738 (1824) (Marshall, C.J.), is frequently interpreted as enunciating the view that original constitutional federal question jurisdiction extends to any case in which there is a potential federal question. See supra note 14. Whether so broad a reading of Osborn is correct was discussed but left open by the Court in Verlinden B.V. v. Central Bank, 103 S. Ct. 1962, 1971 (1983). See also infra note 25 and accompanying text (discussing Verlinden).

${ }^{24}$ E.g., protecting federal rights and insuring uniform interpretation of federal law. See supra note 10 and accompanying text.

${ }_{2 s}$ This conclusion, however, insofar as it suggests that the well-pleaded complaint rule ought to be read as a limitation on the reach of article III, appears to be inconsistent with the Court's recent conclusion that the well-pleaded complaint rule is solely a matter of statutory interpretation. Verlinden B.V. v. Central Bank, 103 S. Ct. 1962, 1972 (1983). In Verlinden, the Court upheld $\S 2$ of the Foreign Sovereign Immunities Act of 1976, 28 U.S.C. $\S$ 1330 (1982), which gives the district courts jurisdiction over nonjury civil actions against foreign states. Jurisdiction under $\S 1330$ extends to cases in which the only federal issue is the availability under the Act of the defense of sovereign immunity. The Court stated that the well-pleaded complaint rule is a rule of statutory construction, applicable only to $§ 1331$. 
federal defense may in fact have been raised by the defendant at the time he seeks removal, the application of the rule to bar removal based on a federal defense suggests that this concern is not the only one addressed by the rule.

Unlike the concern with avoiding federal jurisdiction over cases in which issues of federal law are never actually raised, a second reason for limiting original jurisdiction to cases in which the plaintiff relies on federal law does apply to the removal context. This reason, that federal jurisdiction is more appropriate where issues of federal law are likely to dominate, supports the wellpleaded complaint rule provided one accepts the intuitively appealing presumption that if the plaintiff relies on federal law in stating his claim, federal issues are more likely to dominate the action, while if federal law appears only as a defense (or a reply to a defense) to a state-law cause of action, it is likely that many of the dominant issues to be decided will be questions of state law. ${ }^{26}$

Thus, the Court did not apply the rule in Verlinden to invalidate the lower court's assertion of jurisdiction under $\S 1330.103 \mathrm{~S}$. Ct. at 1972-73.

That Verlinden rejected a constitutional basis for the well-pleaded complaint rule is not as certain as it might seem at first glance. The Court did not reach the issue whether jurisdiction could constitutionally be based on a purely speculative potential federal question, because "a suit against a foreign state under this Act necessarily raises questions of substantive federal law at the very outset . . . " Id. at 1971. The Court reasoned that a federal question was necessarily presented in every case under the Act because the Act requires the plaintiff to establish the existence of one of the statutorily specified exceptions to the defense of sovereign immunity in order to establish federal subject-matter jurisdiction. Id. at 1971 \& $\mathrm{n} .20$. Under this reasoning, the federal question is in fact raised by the plaintiff's complaint, and the statute in question is perfectly consistent with a constitutional well-pleaded complaint rule. Thus, Verlinden can be read as stopping short of approving original jurisdiction based on a federal question that has not been raised at the time jurisdiction attaches.

Even if Verlinden does provide authority for the proposition that the well-pleaded complaint rule is not constitutionally mandated, it is clear that if the notion of limited jurisdiction is to have any meaning at all, there must be a line drawn beyond which the mere possibility of a federal question arising is too remote to countenance an assertion of federal jurisdiction. See supra note 23 and accompanying text. Where there has been a narrow grant of jurisdiction over a specific class of cases, such as the jurisdictional grant at issue in Verlinden, it is relatively certain that a federal question will be presented, even where it has not been raised in the complaint. Where the jurisdictional grant is general, such as that in $\S$ 1331 , however, an interpretation of article III which would allow original federal jurisdiction over any case that contained even the mere possibility of a federal question, would allow unlimited federal jurisdiction since every case contains at least such a possibility, see supra note 23 and accompanying text. There, a constitutional rule delineating those instances in which the potential federal question is too speculative is necessary to preserve any scope for state jurisdiction in the face of a general grant of federal question jurisdiction.

${ }^{28}$ That selecting those cases in which federal issues are more likely to dominate is in fact the more likely purpose of the rule is supported not only by cases that rely on such an analysis to decide whether the rule applies, see Franchise Tax Board, 103 S. Ct. 2841; Skelly Oil Co. v. Phillips Petroleum Co. 339 U.S. 667 (1950), but by operation of the rule itself. 
Thus, the well-pleaded complaint rule may be regarded as limiting federal jurisdiction to cases in which federal issues are likely to predominate. Though this rationale serves to justify the rule, it complicates its application. The Mottley Court's formulation of the rule, which requires that the plaintiff's statement of his own cause of action must raise the federal question, ${ }^{27}$ is too crude a tool for application to the many complexities of federal jurisdiction. The Court in Mottley itself found that plaintiff's statement improperly raised a federal question because it did so in anticipation of a defense. Thus, the Court ignored the plaintiff's statement and dismissed for lack of jurisdiction.

The root of the difficulty in applying the Mottley formulation of the rule is the difficulty in determining what the plaintiff's cause of action is in a given case. Mottley is unclear about the extent to which the court should rely on "the plaintiff's statement" or look beyond the face of the complaint to determine if his cause of action really does involve federal issues. As a consequence, the Court was required in subsequent cases to refine the well-pleaded complaint rule.

Early cases emphasized those aspects of the Mottley formulation of the well-pleaded complaint rule that focused on "the plaintiff's statement." While recognizing that a plaintiff could not obtain a federal forum by anticipating a defense (the Mottley case itself), these cases generally considered the language of the complaint dispositive. The leading authority for this approach is Gully v. First National Bank, ${ }^{28}$ in which the Court held that removal of an action to collect a state tax by levying on assets of a taxpayer held by a national bank could not properly be based on a federal statute permitting states to tax national banks. Justice Cardozo, writing for the Court, traced the confused course of opinions that attempted to ascertain whether a suit arises under federal law, ${ }^{29}$ and concluded that the federal question "must be an element, and

Removal is not permitted when the defendant raises a federal defense, and thus presumably has an interest in having it adjudicated in a federal forum. Nor does a given plaintiff have access to federal courts when, as the issues have developed, he relies, by way of replication, on assertion of a federal right. The logical inference from these observations is that it is concern for the issues alone, and not for the parties, which is at work, and, in fact, the federal courts will not take jurisdiction under $\S 1331$ unless it is more than likely that federal issues will predominate, even where the complaint raises a federal question on its face. See Wechsler, supra note 21, at 233-34; cf. infra notes 43-44 and accompanying text (discussing the search for the underlying cause of action in the declaratory judgment context).

${ }^{27}$ Mottley, 211 U.S. at 152.

28299 U.S. 109 (1936).

29 Id. at 112-16. 
an essential one, of the plaintiff's cause of action . . . and . . . must be disclosed upon the face of the complaint unaided by the answer or by the petition for removal . . . ."so Although this language has its antecedents in Mottley, ${ }^{31}$ Gully placed particular emphasis on a strict limitation to the language of the plaintiff's complaint. Gully incorporates into the well-pleaded complaint rule the doctrine that the plaintiff is master of his own complaint, ${ }^{32}$ since, under Gully, the complaint is considered to be absolutely dispositive of the cause of action.

This focus on the language of the plaintiff's complaint seems intended to simplify the application of the well-pleaded complaint rule. The limitation to the language of the complaint itself, according to Justice Cardozo, is the product of considerable experience with the difficulties of applying the rule and a resulting desire to find a formulation that is simple to apply. ${ }^{33}$ The advantages of such a formulation in terms of administrability are obvious. Gully's focus on the language of the complaint saves considerable time and expense, and enhances the predictability, reliability, uniformity, and reviewability of results. ${ }^{34}$ Indeed, strict adherence to

so Id. at 112-13 (emphasis added).

st See 211 U.S. at 152; supra text accompanying note 18.

${ }^{32}$ See The Fair v. Kohler Die \& Specialty Co., 228 U.S. 22, 25 (1913). The relationship between the plaintiff's mastery of his complaint and original federal question jurisdiction was also pointed out in The Fair: "[T] he party who brings a suit . . . determine[s] whether he will bring a 'suit arising under' [federal law]. That question cannot depend upon the answer . . . ." 228 U.S. at 25. This statement was qualified in a dictum later in the opinion, id.; see infra note 36, and appears to be inconsistent with the rationale of Franchise Tax Board, see infra notes $118-21$ and accompanying text.

ss Justice Cardozo specifically rejected as "hazard[ous]" the argument that the Court should look beyond the face of the complaint in order to determine the true character of the plaintiff's "cause of action." " 299 U.S. at 117. He argued that "[w] hat is needed is something of that common-sense accomodation of judgment to kaleidoscopic situations which characterizes the law in its treatment of causation," $i d$., and contended that the wellpleaded complaint rule, with the limitation to the face of the complaint, was the product of "a selective process which picks the substantial causes out of the web and lays the other ones aside," id. at 118. The rule formulated as a result of this experience, he concluded, must be adhered to: "We shall be lost in a maze if we put that compass by." Id.

s4 One might also justify the Gully formulation of the rule by arguing that the Court should restrict its analysis to the complaint out of deference to a plaintiff's right to waive any federal rights he may have and plead only his state law claims. This rationale is inadequate for several reasons. First, nowhere in Gully is it mentioned as a consideration for the rule, while simplicity of application figures prominently in Justice Cardozo's opinion. See supra note 33. Second, a plaintiff's right to waive any federal claims he has is not denied by looking beyond his complaint. The question is, rather, how deeply the court may examine the case in order to determine whether a plaintiff is asserting such claims. The difficulty arises from the close relation the right to waive federal claims bears to the plaintiff's right to choose a forum. For a demonstration that the plaintiff's right to choose a forum cannot justify the application of the well-pleaded complaint rule in the removal context, see infra 
the Gully language-of-the-complaint requirement would make the jurisdictional inquiry a very simple one, since the court need consider only a single document.

Other facets of the well-pleaded complaint rule, however, suggest that administrative convenience and the plaintiff's mastery of his own complaint are of secondary importance in applying the rule. For example, Mottley requires courts to disregard those of plaintiff's allegations that anticipate a defense, ${ }^{35}$ thereby limiting the plaintiff's mastery of his own complaint and evincing the court's willingness to hazard the administratively more difficult inquiry into which allegations in a complaint are essential. ${ }^{36}$ Furthermore, the application of the well-pleaded complaint rule to removal does not appear to be motivated by concern for the plaintiff's mastery of his complaint. ${ }^{37}$ Finally, the refusal to consider the language of the removal petition or answer cannot be said to enhance significantly the administrability of the rule, ${ }^{38}$ par-

note 37.

ss See supra notes 17-20 and accompanying text.

se The Court in The Fair v. Kohler Die \& Specialty Co., 228 U.S. 22, 25 (1913), noted in dicta that "if it should appear that the plaintiff was not really relying upon [federal law] for his alleged rights . . . the case might be dismissed [for lack of jurisdiction]." See also supra notes 16-19 and accompanying text (discussing Mottley).

Of course, there is a difference between determining that a plaintiff has pleaded too much and looking beyond the complaint to see whether the plaintiff has pleaded enough. With the former inquiry, the court may stop at the complaint and apply established rules of law to the stated cause of action in order to decide which elements are part of the prima facie case and which anticipate affirmative defenses. Nonetheless, even this inquiry will often be extremely difficult, especially in light of modern notice pleading rules. See infra note 39 and accompanying text.

${ }^{37}$ Removal does not affect the plaintiff's cause of action; it does, however, limit his traditionally unfettered choice of a forum, often considered a corollary to the plaintiff's mastery of his complaint. The application of the well-pleaded complaint rule to deny federal defense removal cannot be based on an overriding desire to preserve the plaintiff's choice of forum. See supra notes 25-27 and accompanying text. It would be wholly anomalous to allow a defendant to defeat the plaintiff's actual choice of forum, state court, in order to have the plaintiff's rights vindicated in a federal forum, while holding the plaintiff's choice of a nonfederal forum to be dispositive when the defendant asserts a federal right. This anomaly will, of course, be present to some degree as long as $\$ 1441$ predicates removal on the availability of federal jurisdiction as an original matter. See Wechsler, supra note 21, at 233-34.

ss To the extent that the well-pleaded complaint rule is intended to insure that federal law has in fact been raised by the party relying on it, the court need only read the answer or removal petition to see whether there is any reliance on federal law. Insofar as the number of pleadings to be considered remains limited, there would be little or no loss in any of the factors served by administratively simple rules: cost and time savings, predictability, reliability, uniformity, and reviewability. 
ticularly with the advent of lenient notice pleading under the Federal Rules of Civil Procedure. ${ }^{39}$

An alternative reading of the Mottley decision emphasizes the phrase "cause of action." Under this approach to the well-pleaded complaint rule, the court may look beyond the plaintiff's complaint in order to establish the true nature of the underlying dispute as either state or federal. A striking example of this reading, surprisingly enough, ${ }^{40}$ is found in Skelly Oil Co. $v$. Phillips Petroleum Co., ${ }^{41}$ where the Court held that original jurisdiction over declaratory judgment actions must be tested by reference to an underlying action for damages or injunction rather than the complaint for declaratory relief. ${ }^{22}$ Thus, although the complaint for declaratory relief in Skelly Oil properly alleged a federal right relied upon by the declaratory judgment plaintiff, the Court held that the federal right was "injected into the case only in anticipation of a defense" because the underlying contract claim arose under state law. ${ }^{43}$ Skelly Oil presents a very different view of the well-pleaded complaint rule from that expressed in Gully. Under Skelly Oil, it is incumbent upon a court to look beyond a declaratory judgment complaint's proper reliance on federal law in order to recharacterize the cause of action in terms of the underlying dispute. The Court must construct a hypothetical law suit and examine that suit

39 It is noteworthy that Gully was decided before the adoption, in 1938, of notice pleading in the Federal Rules of Civil Procedure. See Fed. R. Civ. P. 86 (1938), in 309 U.S. 645, 766 (1939). Modern pleading requirements are more lax even than those of the Field Code in force in Gully. The effect of modern pleading rules is difficult to measure, however, since courts that have abandoned the Gully approach for a more open-ended inquiry into the underlying nature of the plaintiff's cause of action have not attributed any significance to the state of pleading rules. See, e.g., Franchise Tax Bd. v. Construction Laborers Vacation Trust, 103 S. Ct. 2841 (1983); Skelly Oil Co. v. Phillips Petroleum Co., 339 U.S. 667 (1950); see also infra notes 49-94 and accompanying text (discussing approaches that look beyond the face of the complaint).

to It is surprising because Justice Frankfurter, no friend of expansive federal jurisdiction, rejected the Gully language-of-the-complaint standard and looked through the plaintiff's complaint to the underlying cause of action in order to avoid an expansion of federal jurisdiction arising from the Declaratory Judgment Act, Pub. L. No. 343, 48 Stat. 955 (1934) (current version at 28 U.S.C. \& 2201 (1982)). See Skelly Oil, 339 U.S. at 671-72. Part II of this comment demonstrates that the lower courts adopted a similar integration of the wellpleaded complaint rule in order to expand federal jurisdiction in preemption removal cases. It is this theory of the well-pleaded complaint rule that Franchise Tax Board adopts. See infra notes 113-22 and accompanying text. Thus, the approach has come full circle: used by the Supreme Court to limit federal jurisdiction in Skelly Oil, it is picked up by the lower courts as a means of expanding federal jurisdiction in preemption removal cases and is finally reembraced by the Supreme Court in that guise in Franchise Tax Board.

42339 U.S. 667 (1950).

42 Id. at $671-74$.

13 Id. at 672 . 
to determine whether or not the genuine dispute is based on state or federal law.44

To the extent that Skelly Oil requires the courts, in applying the well-pleaded complaint rule, to unravel declaratory judgment actions in order to identify the underlying cause of action, a certain consistency is imposed on the application of the well-pleaded complaint rule. Whether the action is one originally filed in federal court, an action removed to federal court by the defendant, or a declaratory judgment action, jurisdiction is tested on the basis of the cause of action of the party who actually or hypothetically seeks affirmative relief. This consistency is achieved, however, at the price of administrative convenience.

It is still necessary to ask how the purposes of the wellpleaded complaint rule are served by requiring the court to identify the underlying cause of action in declaratory judgment actions. The complaint for declaratory relief properly relies on federal law, so that federal law has been raised at the time jurisdiction attaches. The essential purpose of the well-pleaded complaint rule, however, is to screen out cases that are primarily state-law mat-

"Although the Court rested its holding in Skelly Oil in part on its interpretation of the Declaratory Judgment Act, Pub. L. No. 343, 48 Stat. 955 (1934) (current version at 28 U.S.C. \& 2201 (1982)), the Court also discussed the importance of preserving general limits on original federal jurisdiction: "[It] would turn into the federal courts a vast current of litigation indubitably arising under State law, in the sense that the right to be vindicated was State-created, if a suit for a declaration of rights could be brought into the federal courts merely because an anticipated defense derived from federal law." 339 U.S. at 673.

This language suggests that the application of the well-pleaded complaint rule to the declaratory judgment claims is not merely an interpretation of the Declaratory Judgment Act, but rather also furthers the purposes of the well-pleaded complaint rule itself. This conclusion is supported by the extension, in Franchise Tax Board, of the Skelly Oil principle to declaratory judgment proceedings brought pursuant to state statutes. Franchise Tax Board, 103 S. Ct. at 2851. The Franchise Tax.Board Court based its extension of Skelly Oil to state declaratory judgment statutes at least in part upon an effort to preserve the intended limits of the federal declaratory judgment statute, $i d$. at 2851, and one might argue that this extension is thus merely a preemptive application of the federal statute. However, this argument attributes a great deal of force to a legislative intent that was only inferred in Skelly Oil itself. See Skelly Oil, 339 U.S. at 671, where the Court relied on a statement in Aetna Life Ins. Co. v. Haworth, 300 U.S. 227, 240 (1937), that the Declaratory Judgment Act was "procedural only." The Aetna Court, however, was concerned with the question whether the Declaratory Judgment Act had impermissibly given federal courts jurisdiction over matters not cases or controversies within the limitation of article III, and did not purport to address the Act's effect on federal question jurisdiction. See Aetna, 300 U.S. at 23940. The Shelly Oil Court simply applied the language quoted from Aetna to the problem of assessing the existence of federal question jurisdiction over actions brought pursuant to the Act without explanation or qualification. A more plausible explanation for the Court's decision in Franchise Tax Board is that the Skelly Oil principle inheres in the nature of the jurisdictional inquiry as applied to declaratory judgment actions. See Skelly Oil, 339 U.S. at 673. 
ters, even though a federal issue lurks in the background..$^{45}$ The unusual procedural posture a case assumes as a result of the declaratory judgment remedy makes Gully's focus on the language of the complaint inadequate. It is precisely to accomplish the objectives of the well-pleaded complaint rule that the Court abandons Gully and examines the underlying nature of the dispute.

As the above discussion suggests, it was difficult to find a single consistent method for applying the well-pleaded complaint rule, despite its long history as the standard for assessing statutory federal question jurisdiction. The competing approaches exemplified by Gully and Skelly Oil rendered application of the rule in complex areas difficult, and led to confusing and often contradictory results. ${ }^{46}$ Thus, it is not surprising that the lower federal courts were in "disarray" over the preemption removal problem. ${ }^{47}$

\section{Preemption Removal in the Lower Courts}

The preemption removal problem is of relatively recent origin, perhaps because it was not until recently that the proliferation of federal regulation provided such an expansive field in which federal law might be said to preempt state law under the supremacy clause of article VI.48 Perhaps responding to the perceived need to

15 See supra notes $25-27$ and accompanying text.

16 For example, where a party seeks an injunction against the enforcement of an allegedly unconstitutional state law, his position is virtually identical to that of a plaintiff seeking a declaration that the law is unconstitutional. Both plaintiffs anticipate an "underlying" action based on state law. In the injunction context, however, the court makes its jurisdictional determination on the basis of the complaint for injunctive relief, rather than attempting to recharacterize the claim in terms of an "underlying" cause of action. See, e.g., Ex parte Young, 209 U.S. 123 (1908).

Another example of such difficulties is the Court's inconsistent treatment of original jurisdiction in cases based on the incorporation of federal law into a state law cause of action. Compare, e.g., Smith v. Kansas City Title \& Trust Co., 255 U.S. 180, 201 (1921) (upholding federal jurisdiction over a state law action against a trust for investment in invalid securities, where validity of securities turned on federal law), and Standard Oil Co. v. Johnson, 316 U.S. 481, 483 (1942) (upholding federal jurisdiction over action by post exchange to recover state taxes based on state law exempting United States government from tax, where status of post exchange as part of the United States government was a question of federal law), with Moore v. Chesapeake \& O. Ry., 291 U.S. 205, 214-17 (1934) (denying federal jurisdiction over state action incorporating standards of the Federal Safety Appliance Acts). For further discussion of the incorporation problem, see Note, 66 HARv. L. REv. 1498 (1953). See also infra notes $49-94$ and accompanying text (discussing the preemption removal problem in the lower courts).

47 Brown \& Sharpe Mfg. Co. v. Members of Lodges 1088 \& 1142, Internat'l Ass'n of Machinists, 535 F. Supp. 167, 169 n.1 (D.R.I. 1982).

48 U.S. Const. art. VI, cl. 2. Fay v. American Cystoscope Makers, Inc., 98 F. Supp. 278 (S.D.N.Y. 1951), was apparently the first reported case allowing preemption removal. Since the 1951 decision in Fay, the preemption removal issue has appeared rather regularly in the 
vindicate strong federal policy interests in areas of pervasive federal regulation, the lower courts advanced various related theories for allowing removal based on preemption despite the fact that preemption was first raised defensively. ${ }^{49} \mathrm{~A}$ number of courts, however, applied the well-pleaded complaint rule flatly to reject preemption removal. ${ }^{50}$

\section{A. The Emergence of Preemption Removal}

This apparent conflict between the requirements of the wellpleaded complaint rule and the need for a federal forum to vindicate strong federal interests first surfaced in the field of labor law. In Textile Workers Union v. Lincoln Mills, ${ }^{51}$ the Court held that section 301 of the Labor Management Relations Act of 1947 ("LMRA") 52 empowered the courts to create a body of federal common law. The Court reasoned that the statute "expresses a federal policy that the federal courts should enforce [collective bargaining] agreements." be defeated, however, if a plaintiff could avoid federal jurisdiction by refusing to allege federal law in his complaint..$^{54}$

courts. See, e.g., Avco Corp. v. Aero Lodge No. 735, 390 U.S. 557 (1968), aff'g, 376 F.2d 337 (6th Cir. 1967); Johnson v. England, 356 F.2d 44 (9th Cir. 1966); Hearst Corp. v. Shopping Center Network, Inc., 307 F. Supp. 551 (S.D.N.Y. 1969); Sylgab Steel \& Wire Corp. v. Strickland Transp. Co., 270 F. Supp. 264 (E.D.N.Y. 1967); Swift \& Co. v. United Packinghouse Workers, 177 F. Supp. 511 (D. Colo. 1959); Minkoff v. Scranton Frocks, Inc., 172 F. Supp. 870 (S.D.N.Y. 1959); Irving Subway Grating Co. v. Silverman, 117 F. Supp. 671 (E.D.N.Y. 1953). For further discussion of Fay, see infra notes 55-59 and accompanying text.

11 See infra notes 69-71, 79-83 and accompanying text. It is interesting to note that the first reported case allowing preemption removal, Fay v. American Cystoscope Makers, Inc., 98 F. Supp. 278 (S.D.N.Y. 1951), was handed down in the year following Skelly Oil. Whether the court took Skelly Oil as a sign that it was proper to look beyond the complaint is difficult to know, since Fay does not cite Skelly Oil, but it would be at least somewhat ironic if the latter opinion, which expressed a policy against expanding federal jurisdiction, see supra note 44, were discovered to provide implicit support for that result.

${ }^{30}$ See infra notes $72-78$ and accompanying text.

31353 U.S. 448 (1957).

${ }^{32} 29$ U.S.C. $\$ 185$ (1982).

ss 353 U.S. at 455 . Lincoln Mills itself did not hold that $\S 301$ of the LMRA preempted the entire field of labor law. The questions of concurrent state jurisdiction and the status of state law remedies in state courts were left open.

of Several qualifications are necessary. First, since federal jurisdiction under $\S 301$ is not exclusive, see supra note 53, any inference of the policy favoring federal enforcement is somewhat weakened. Second, one can argue that, insofar as the policy is, at bottom, a defendant's right to a federal forum, it begs the question to assert that there is a conflict between the plaintiff's mastery of his complaint and the defendant's right to a federal forum: if the well-pleaded complaint rule bars removal, defendant has no such right and the interest identified is one protected by appeal rather than by removal. See supra note 24 . This com- 
This difficulty was presented to the federal district court in Fay v. American Cystoscope Makers, Inc. ${ }^{56}$ which also involved jurisdiction under section 301 of the LMRA, and is the seminal case for allowing preemption removal. ${ }^{56}$ Although the plaintiff in Fay couched his complaint solely in terms of state law, the court invoked the rule that "where federal jurisdiction hinges on the parties', or one of them, having a particular status, the court may ascertain the existence of that status independently of the complaint." 67 The plaintiff"s status as "a union representing employees in an industry affecting commerce" placed it within the ambit of section $301 .{ }^{58}$ The court held that in light of the creation of a body of substantive federal law under section 301 , federal law had preempted the field of collective bargaining agreements, and the plaintiff therefore could not choose to rely solely on state law. ${ }^{59}$

In Avco Corp. v. Aero Lodge No. $735,{ }^{60}$ the Supreme Court tacitly approved the Fay rationale. The plaintiff in Avco did not rely on federal law in his complaint, but the court of appeals approved removal based on reasoning similar to that in Fay. ${ }^{61}$ The Supreme Court upheld jurisdiction without mentioning the wellpleaded complaint rule, stating simply that "[a]n action arising under $\S 301$ is controlled by federal substantive law even though it is brought in a state court." 62 Thus, it was "clear" that the claim

ment will argue that such an analysis is inappropriate after Franchise Tax Board, which acknowledges the power of the court to look beyond the complaint and recharacterize the dispute in order to vindicate the particularly strong federal interest associated with certain kinds of preemption. See infra notes 113-22 and accompanying text.

ss 98 F. Supp. 278 (S.D.N.Y. 1951).

ss Fay could not rely on Lincoln Mills to establish § 301 preemption; Lincoln Mills was decided six years later. Fay cited Shirley-Herman Co. v. International Hod Carriers, 182 F.2d 806 (2d Cir. 1950), a precursor of Lincoln Mills, to establish $\S 301$ preemption.

${ }^{87} 98 \mathrm{~F}$. Supp. at 280 . The court explained that the status rule previously had been applied to ascertain the existence of diversity of citizenship, and the federal nature of a receiver, a corporation, and a marshal. Id.

ss Id. at 280-81.

so Id.

so 390 U.S. 557 (1968). Avco was relied on by the Court in Franchise Tax Board. See

$103 \mathrm{~S}$. Ct. at 2853; infra notes $105-12$ and accompanying text.

61 See Avco Corp. v. Aero Lodge, 376 F.2d 337, 339-40 (6th Cir. 1967), aff'd, 390 U.S.

557 (1968). Citing Lincoln Mills, the court of appeals stated:

State law does not exist as an independent source of private rights to enforce collective bargaining contracts. While State courts may have concurrent jurisdiction, they are bound to apply Federal law. . . . The force of Federal preemption in this area of labor law cannot be avoided by failing to mention Section 301 in the complaint.

Id. at 340 (citation omitted). Consequently, the court held, Avco's claim arose under federal law and removal was proper. $I d$.

62390 U.S. at 560 (footnote omitted). While the Supreme, Court has stated that "when questions of jurisdiction have been passed on in prior decisions sub silentio, th[e] Court has 
was within the original jurisdiction of the district court, and hence properly removed. ${ }^{63}$ After $A v c o$, preemption removal became well established in the field of labor law. ${ }^{64}$

The success of preemption removal in the labor law context encouraged defendants to seek removal based on allegations of federal preemption in other regulatory contexts such as interstate shipping, ${ }^{65}$ intellectual property, ${ }^{68}$ and banking. ${ }^{67}$ Attempts to re-

never considered itself bound when a subsequent case finally brings the jurisdictional issue before [the Court]," Hagans v. Lavine, 415 U.S. 528, 535 n.5 (1974), the applicability of that principle in interpreting Avco is open to question. The Hagans Court referred to jurisdictional questions raised after decisions rendered on the merits without any consideration of jurisdiction at all. Avco on the other hand was a specific challenge to removal based on the lack of original jurisdiction in the federal courts. Consequently, the question of jurisdiction was not passed on sub silentio, and unless the Hagans principle is to be extended to encompass the proposition that every subsidiary issue not specifically discussed in an opinion is completely open, Avco must be taken as at least some support for preemption removal. Of course, after Franchise Tax Board the specfic issue is moot. See infra notes 96-122 and accompanying text.

es 390 U.S. at 560. Even assuming the existence of a federal question in the complaint, the Avco opinion is somewhat obscure about the statutory basis for federal jurisdiction. Since $\S 301$ is itself a grant of jurisdiction, one might assume that it confers federal jurisdiction over the body of federal common law it authorizes the courts to create. If that were the case, failure to mention the well-pleaded complaint rule would be understandable, since $\S 301$, as a narrow grant of jurisdiction, might be seen as one to which the well-pleaded complaint rule, as a principle of statutory interpretation, need not apply. See supra note 25 (discussing the applicablity of the well-pleaded complaint rule to narrow, as opposed to general, grants of jurisdiction). However, Justice Douglas, writing for a unanimous Court, rested federal jurisdiction not directly on $\S 301$ but on 28 U.S.C. $\$ 1337$ (1982), which is a general grant of federal jurisdiction over "proceedings" related to commerce. 390 U.S. at 561-62. In light of this rationale, it is somewhat surprising that the well-pleaded complaint was never mentioned, much less applied.

oe See, e.g., Johnson v. England, 356 F.2d 44 (9th Cir. 1966); Billy Jack For Her, Inc. v. New York Coat Workers Union, Local 1-35, 511 F. Supp. 1180 (S.D.N.Y. 1981); Teamsters Local Union 116 v. Fargo-Moorhead Auto. Dealers Ass'n, 459 F. Supp. 558 (D.N.D. 1978); Hayes v. C. Schmidt \& Sons, Inc., 374 F. Supp. 442 (E.D. Pa. 1974); Comment, Intimations of Federal Removal Jurisdiction in Labor Cases: The Pleading Nexus, 1981 Duke L.J. 743, 745-46; see also Jones v. General Tire \& Rubber Co., 541 F.2d 660, 663-65 (7th Cir. 1976) (holding removal improper because defendant did not establish labor contract as the basis of plaintiff's claim, therefore rendering $\S 301$ inapplicable). Even courts that otherwise rejected preemption removal recognized the validity of removal in the labor law context. See, e.g., First Nat'l Bank v. Aberdeen Nat'l Bank, 627 F.2d 843, 853 (8th Cir. 1980).

os See, e.g., North Am. Phillips Corp. v. Emery Air Freight Corp., 579 F.2d 229 (2d Cir. 1978) (approving removal of action involving air carrier liability); Sylgab Steel \& Wire Corp. v. Strickland Transp. Co., 270 F. Supp. 264 (E.D.N.Y. 1967) (approving removal of action involving liability of common carriers).

-6 See, e.g., La Chemise Lacoste v. Alligator Co., 506 F.2d 339 (3d Cir. 1974) (rejecting preemption removal in trademark context), cert. denied, 421 U.S. 937 (1975); Bailey v. Logan Square Typographers, Inc., 441 F.2d 47 (7th Cir. 1971) (rejecting preemption removal doctrine in copyright context); Coditron Corp. v. AFA Protective Sys., Inc., 392 F. Supp. 158 (S.D.N.Y. 1975) (recognizing preemption removal doctrine but denying removal of patent action because of lack of preemption); Gardner v. Clark Oil \& Refining Corp., 383 F. Supp. 
move in these contexts met with mixed success. ${ }^{68}$

The principal argument advanced by lower courts for allowing preemption removal was that where there has been federal preemption, the complaint necessarily presents a federal cause of action. ${ }^{69}$ Under this rationale, the court merely determines the real nature of the plaintiff's cause of action and since, by virtue of federal preemption, the complaint necessarily presents a federal cause of action, removal does not violate the well-pleaded complaint rule. $^{70}$ Occasionally, courts went so far as to suggest that there was an exception to the well-pleaded complaint rule whenever a preemption defense was raised, reasoning that the existence of pre-

151 (E.D. Wis. 1974) (recognizing preemption removal doctrine but denying removal of trademark action because of lack of preemption); In re New York, 362 F. Supp. 922 (S.D.N.Y. 1973) (rejecting preemption removal doctrine); Hearst Corp. v. Shopping Center Network, Inc., 307 F. Supp. 551 (S.D.N.Y. 1969) (recognizing preemption removal doctrine, but holding that absence of statutory copyright meant that plaintiff lacked the requisite status to bring the action under federal law).

${ }^{67}$ See, e.g., Nalore v. San Diego Fed. Sav. \& Loan Ass'n, 663 F.2d 841 (9th Cir. 1981) (denying removal because allegedly preempting federal regulation of homeowners loans did not provide a superseding cause of action), cert. denied, 455 U.S. 1021 (1982); Trent Realty Assocs. v. First Fed. Sav. \& Loan Ass'n, 657 F. 2d 29 (3d Cir. 1981) (rejecting preemption removal doctrine in context of federal regulation of homeowners loans); Guinasso v. Pacific First Fed, Sav. \& Loan Ass'n, 656 F.2d 1364 (9th Cir. 1981) (denying removal because allegedly preempting federal regulation of homeowners loans did not provide a superseding cause of action), cert. denied, 455 U.S. 1020 (1982); Madsen v. Prudential Fed. Sav. \& Loan Ass'n, 635 F.2d 797 (10th Cir. 1980) (rejecting preemption removal doctrine in context of federal savings and loan regulation), cert. denied, 451 U.S. 1018 (1981); First Nat'l Bank v. Aberdeen Nat'l Bank, 627 F.2d 843 (8th Cir. 1980) (rejecting preemption removal doctrine in context of national bank regulation); North Davis Bank v. First Nat'l Bank, 457 F.2d 820 (10th Cir. 1972) (allowing preemption removal in context of national bank regulation); Smart v. First Fed. Sav. \& Loan Ass'n, 500 F. Supp. 1147 (E.D. Mich. 1980) (rejecting preemption removal doctrine in context of federal regulation of homeowners loans); Turner $\mathrm{v}$. Bell Fed. Sav. \& Loan Ass'n, 490 F. Supp. 104 (N.D. Ill. 1980) (rejecting preemption removal doctrine in context of federal savings and loan regulation); First Fed. Sav. \& Loan Ass'n v. First Fed. Sav. \& Loan Ass'n, 446 F. Supp. 210 (N.D. Ala. 1978) (allowing preemption removal in context of federal regulation of homeowners loans); Rettig v. Arlington Heights Fed. Sav. \& Loan Ass'n, 405 F. Supp. 819 (N.D. Ill. 1975) (allowing preemption removal in context of federal regulation of homeowners loans).

${ }^{68}$ See cases cited supra notes 65-67.

68 See, e.g., Salveson v. Western States Bankcard Ass'n, 525 F. Supp. 566, 572 (N.D. Cal. 1981); Teamsters Local Union 116 v. Fargo-Moorhead Auto. Dealers Ass'n, 459 F. Supp. 558, 561 (D.N.D. 1978); First Fed. Sav. \& Loan Ass'n v. First Fed. Sav. \& Loan Ass'n, 446 F. Supp. 210, 212 (N.D. Ala. 1978); Rettig v. Arlington Heights Fed. Sav. \& Loan Ass'n, 405 F. Supp. 819, 823 (N.D. Ill. 1975).

${ }^{70}$ See, e.g., North Am. Phillips Corp. v. Emery Air Freight Corp., 579 F.2d 229, 234 (2d Cir. 1978)("The allegations of appellant's complaint show that its claim is based upon the loss of goods during interstate transportation [, which] sets forth a claim arising under federal law."); Johnson v. England, 356 F.2d 44, 48 (9th Cir.) ("[A] fair construction of the complaint here filed must be that it is necessarily one pursuant to $\$ 301(\mathrm{a})$ [of the LMRA] . . . "), cert. denied, 384 U.S. 961 (1966). 
emption necessarily meant that a federal question was presented. ${ }^{71}$ Preemption removal met with substantial resistance, however. In La Chemise Lacoste $v$. Alligator Co., ${ }^{72}$ for example, the Court of Appeals for the Third Circuit emphasized that the removal statute should be narrowly construed to protect the jurisdiction of state courts. $^{\text {7s }}$ The court rejected Fay expressly, reasoning that federal district courts should not "engraft exceptions [onto the wellpleaded complaint rule] contrary to the legislative policy so zealously protected by the Supreme Court." ing on Gully, reasoned that since preemption is raised by the defendant, it is indistinguishable from other federal defenses, and cannot be used to convert a complaint that relies on state law into a case arising under federal law. ${ }^{75}$ Moreover, such courts reasoned, comity would best be served by allowing state courts to rule first on the question of preemption, because state courts can be safely trusted to apply federal law ${ }^{76}$ and because there will ultimately be review in a federal forum through appeal to the Supreme Court. ${ }^{77}$

71 See, e.g., City of New Orleans v. United Gas Pipe Line Co., 390 F. Supp. 861, 864 (E.D. La. 1974); Gardner v. Clark Oil \& Refining Corp., 383 F. Supp. 151, 152 (E.D. Wis. 1974). As this comment demonstrates, such an assertion is completely incorrect under the rule of Franchise Tax Board. See infra notes 96-122 and accompanying text. The essence of preemption removal is the recognition that the plaintiff's cause of action is in fact federal, so that removal is allowed within the well-pleaded complaint rule. Under the analysis to be developed in this comment, the basis for removal based on preemption is that the peculiarly strong federal interest which underlies certain instances of preemption is sufficient to displace the ordinary rule of Gully that, for purposes of the well-pleaded complaint rule, the plaintiff is master of his complaint. If federal preemption is not of this nature, but is merely a defense, removal is improper. The problem left by Franchise Tax Board is how to tell one kind of preemption from the other. This comment offers one suggestion. See infra notes 143-57 and accompanying text.

${ }^{72} 506$ F.2d 339, 343-45 (3d Cir. 1974), cert. denied, 421 U.S. 1006 (1975). Lacoste instituted a state law declaratory judgment action in state court. Alligator sought removal, arguing that the Skelly Oil declaratory judgment rule ought to apply and that the court must unravel the complaint in order to determine what the action would be in an ordinary lawsuit. Alligator claimed that the action so revealed was preempted by federal law. The court disagreed, holding that even if the federal declaratory judgment rule were to apply to a state declaratory judgment action, there existed no preemption in the case before it, and therefore, even if Fay were correct, removal would be improper. See id. at 345-46.

${ }^{73}$ Id. at 344-45.

34 Id. at 345 .

${ }^{73}$ See, e.g., First Nat'l Bank v. Aberdeen Nat'l Bank, 627 F.2d 843, 852 (8th Cir. 1980); Washington v. American League of Professional Baseball Clubs, 460 F.2d 654, 660 (9th Cir. 1972); Bailey v. Logan Square Typographers, Inc., 441 F.2d 47, 51-52 (7th Cir. 1971).

${ }^{76}$ See, e.g., Bailey v. Logan Square Typographers, Inc., 441 F.2d 47, 52 (7th Cir. 1971); Freeman v. Colonial Liquors, Inc., 502 F. Supp. 367, 370 (D. Md. 1980); Eure v. NVF Co., 481 F. Supp. 639,643 (E.D.N.C. 1979).

77 See, e.g., Freeman v. Colonial Liquors, Inc., 502 F. Supp. 367, 370 (D. Md. 1980); Johnson v. First Fed. Sav. \& Loan Ass'n, 418 F. Supp. 1106, 1109 (E.D. Mich. 1976). 


\section{B. The Development of Preemption Removal in the Lower Courts}

Preemption removal expanded despite these objections. ${ }^{78}$ Application of preemption removal remained difficult in two respects, however, even for those courts adopting the doctrine. First, as noted above, there was confusion as to the proper understanding of the well-pleaded complaint rule. ${ }^{79}$ Some courts quite understandably read the Gully statement of the rule as requiring the language of the plaintiff's complaint itself to present a federal question, and either rejected preemption removal outright, ${ }^{80}$ or created an exception to the rule in cases where the plaintiff allegedly pleaded in bad faith to avoid the federal issue. ${ }^{81}$ Other courts interpreted the rule to require that the federal question be presented by the plaintiff's cause of action, and therefore considered it proper to look beyond the language of the complaint to identify the cause of action. ${ }^{82}$

A second source of confusion was the difficulty in distinguishing a defense alleging that the plaintiff's state law cause of action had been preempted by federal law from a case in which preemption meant that the plaintiff's cause of action was necessarily a federal one. ${ }^{83}$ Not every court made such a distinction, however. Some courts reasoned that whenever preemption was raised as a defense a federal question was necessarily presented, and removal was therefore proper. ${ }^{84}$

These two difficulties led to confusion among the lower courts over preemption removal. This confusion frequently manifested itself in the adoption of one of two tests for identifying those cases for which preemption removal was appropriate. First, a number of

78 See supra notes 64-68; infra notes 79-94.

79 See supra notes 28-47 and accompanying text.

so See supra notes 72-77 and accompanying text.

81 See infra notes 85-89 and accompanying text. This exception, the so-called "artful pleading" doctrine, is discussed infra notes 87-89 and accompanying text.

s2 See supra notes 69-71 and accompanying text.

${ }^{83}$ Since preemption is raised by a defendant, a number of courts considered preemption removal to be indistinguishable from other federal defenses. For example, in Smart v. First Fed. Sav. \& Loan Ass'n, 500 F. Supp. 1147 (E.D. Mich. 1980), the court stated:

The principal problem with those cases that have held that federal preemption gives rise to jurisdiction is that they merely assert, but do not make an effort to justify a distinction between raising a federal defense, which clearly does not give rise to removal jurisdiction, and raising federal preemption, which they indicate does.

Id. at 1154; see supra note 71; infra notes 143-57 and accompanying text (explaining the difference).

84 See supra note 71 and accompanying text. 
courts focused on the plaintiff's efforts to defeat federal jurisdiction and created the "artful pleading" doctrine. ${ }^{85}$ For example, in Hearst Corp. v. Shopping Center Network, ${ }^{86}$ the court reasoned that "where Congress has explicitly said that the exclusive source of a plaintiff's right to relief is to be federal law, it would be unacceptable to permit that very plaintiff, by the artful manipulation of the terms of a complaint, to defeat a clearly enunciated congressional objective." plaintiff's improper motive is in part a response to the Gully view of the well-pleaded complaint rule that limits the court's inquiry to the face of the complaint. An exception to that construction of the rule is justified on the theory that where a plaintiff misstates the gravamen of his claim, the court may look beyond the complaint to determine the real nature of the claim. ${ }^{88}$ Artful pleading emerged as a dominant theme in analyzing the preemption removal problem. ${ }^{89}$

${ }_{85}$ See, e.g., Louisiana ex rel. Guste v. Fedders Corp., 524 F. Supp. 552, 555-56 (M.D. La. 1981); New York v. Local 144, Hotel, Nursing Home \& Allied Health Servs. Union, 410 F. Supp. 225, 226-229 (S.D.N.Y. 1976); Coditron Corp. v. AFA Protective Syss., 392 F. Supp. 158, 160 (S.D.N.Y. 1975); Hayes v. C. Schmidt \& Sons, 374 F. Supp. 442, 445 (E.D. Pa. 1974); see also 1A J. Moorz, B. Ringle \& J. Wicker, Moork's Frderal Practicr 10.160 [3.3], at 228-36 (2d ed. 1983); 14 C. Wright, A. Miller, \& E. Cooper, Fedrral Practice and Procedure § 3722, at 564 (1975).

307 F. Supp. 551 (S.D.N.Y. 1969).

${ }^{87}$ Id. at 556 (emphasis added). The Hearst court relied on reasoning similar to that in Fay. See supra notes 55-59 and accompanying text. The plaintiff's improper motive and manipulation of his complaint, however, received additional emphasis in Hearst. The analysis in Hearst, indeed the entire artful pleading doctrine, is somewhat circular. The plaintiff's bad faith in avoiding the federal issue is inferred from the conclusion that there has been preemption so that the plaintiff's state cause of action must fail to state a claim upon which relief can be granted. No reason is given why the plaintiff cannot simply waive any federal rights he may have and assert only his state law claim in a state court, subject to a preemption defense. Insofar as the plaintiff has this right, there is no "bad faith" or "artful manipulation" involved. It is this inherent circularity which leads this comment to advocate the abandonment of the artful pleading doctrine. See infra notes 123-33 and accompanying text.

Prior to Franchise Tax Board, there was a conflict in the courts as to whether preemption removal could be proper absent a finding of artful pleading. Compare, e.g., Illinois v. Kerr-McGee Chem. Corp., 677 F.2d 571 (7th Cir.) (denying removal), cert. denied, $103 \mathrm{~S}$. Ct. 469 (1982), with North Am. Phillips Corp. v. Emery Air Freight Corp., 579 F.2d 229 (2d Cir. 1978) (allowing removal).

ss See, e.g., North Davis Bank v. First Nat'l Bank, 457 F.2d 820, 823 (10th Cir. 1972); PLM, Inc. v. Consolidated Rail, 490 F. Supp. 194, 196 (E.D. Pa. 1980); Coditron Corp. v. AFA Protective Sys., Inc., 392 F. Supp. 158, 160 (S.D.N.Y. 1975); 1A J. Moore, B. Ringle \& J. WICKER, supra note 85, at 228-36.

s" See Federated Dep't Stores, Inc. v. Moitie, 452 U.S. 394, 397 n.2 (1981) (artful pleading relied upon to permit removal in order to dismiss for res judicata); In re Wiring Device Antitrust Litig., 498 F. Supp. 79, $82-83$ (E.D.N.Y. 1980); 1A J. MOORE, B. RINGLE \& J. WrCKER, supra note 85 , at 228-36; 14 C. WRIGHT, A. MrLLR, \& E. CoOPRR, supra note 85 , § 3722, at 564. But see Moitie, 452 U.S. at 404-10 (Brennan, J. dissenting) (rejecting Court's exten- 
Second, some courts limited preemption removal to cases where federal law not only preempts state law, but also provides the plaintiff with a superseding cause of action. ${ }^{90}$ In New York $v$. Local 1115 Joint Board, Nursing Home \& Hospital Employees Division, ${ }^{91}$ the court reasoned that " $[\mathrm{w}]$ here . . . superseding federal law does not replace rights formerly granted by State law, it is illogical to say that the litigant's claim is really predicated on a body of law which grants him no rights." 92 This rationale is frequently used to distinguish cases in which federal preemption is merely a defense from cases in which preemption removal is considered proper. ${ }^{93}$ The superseding cause of action rationale also occasionally appears in combination with the artful pleading doctrine..$^{94}$

These cases provide the background against which Franchise Tax Board v. Construction Laborers Vacation Trust ${ }^{95}$ was decided. The lower courts had reflected the ambiguity in the wellpleaded complaint rule in their uncertainty over whether the court should limit its inquiry to the complaint or engage in an analysis of the underlying nature of the plaintiff's cause of action. Having generally accepted the latter approach in the preemption removal context, the lower courts then added to the confusion by providing

sion of the artful pleading doctrine beyond the preemption context). For a discussion of the artful pleading doctrine in light of Franchise Tax Board, see infra notes 123-33 and accompanying text. For further discussion of Moitie, see infra note 126 and accompanying text.

00 See, e.g., Guinasso v. Pacific First Fed. Sav. \& Loan Ass'n, 656 F.2d 1364, 1367 (9th Cir. 1981), cert. denied, 455 U.S. 1020 (1982); Long Island R.R. v. United Transp. Union, 484 F. Supp. 1290, 1293 (S.D.N.Y. 1980); New York v. Local 1115 Joint Bd., Nursing Home \& Hosp. Employees Div., 412 F. Supp. 720, 723 (E.D.N.Y. 1976).

91 412 F. Supp. 720 (E.D.N.Y. 1976).

${ }^{22}$ Id. at 723 .

${ }^{23}$ See, e.g., Guinasso v. Pacific First Fed. Sav. \& Loan Ass'n, 656 F.2d 1364, 1366-67 (9th Cir. 1981), cert. denied, 455 U.S. 1020 (1982).

${ }^{4}$ See, e.g., Long Island R.R. v. United Transp. Union, 484 F. Supp. 1290, 1292-93 (S.D.N.Y. 1980). The artful pleading doctrine and the superseding cause of action requirement are often treated as variations of the same principle. Artful pleading is frequently little more than a label attached to the plaintiff's failure to plead a superseding cause of action, and the presence of a superseding cause of action simply establishes the conditions under which artful pleading can occur. Since both doctrines derive from the difficulty of ascertaining precisely when the plaintiff's cause of action is necessarily a federal one, in many cases it is true that they are one and the same. Analytically, however, and quite often in application, they remain distinct concepts. Artful pleading involves an element of improper intent, which may be present or absent independently of whether or not the preempting federal law also provides a superseding cause of action. The tendency of the courts to merge these approaches has obscured both this analytical difference and the real underlying basis for removal. As a result, little attention has been devoted to considering the appropriateness either of examining the plaintiff's motive as a factor in determining whether removal is proper or of requiring a superseding cause of action. This comment attempts to do both. See infra notes $123-57$ and accompanying text.

${ }^{28} 103$ S. Ct. 2841 (1983). 
additional limitations on when preemption removal applied. These limitations took the form of the related but distinct artful pleading doctrine and superseding cause of action requirement. Franchise Tax Board provided the Supreme Court with an opportunity to clarify these issues.

\section{Franchise Tax Board}

Franchise Tax Board involved an attempt by the plaintiff California Franchise Tax Board (the "Board") to recover unpaid taxes by attaching a taxpayer's interest in the defendant Construction Laborers Vacation Trust (the "Trust"). Because the Trust was covered by the Employee Retirement Income Security Act ("ERISA"), ${ }^{98}$ the Board expected that the Trust would assert that ERISA preempted the Board's state law cause of action. Therefore, in addition to its attachment action, the Board filed a separate claim for declaratory relief that its attachment claim was not preempted by ERISA.97 The Trust removed the case to federal district court, asserting preemption under ERISA as the basis for federal jurisdiction. ${ }^{88}$ The district court allowed removal, and held for the Board on the merits. ${ }^{99}$ The Supreme Court never reached the merits, holding apologetically that the district court had improperly allowed removal. ${ }^{100}$ Justice Brennan had little difficulty in concluding that preemption under ERISA was merely a defense to the Board's state-law attachment claim. ${ }^{101}$ The Court then turned to the Board's complaint for declaratory relief, which on its face presented a federal question of the preemptive effect of ERISA on the Board's state law attachment claim. The Court extended to state-court declaratory judgment actions removed to federal court the Skelly Oil Co. v. Phillips Petroleum Co. ${ }^{102}$ rule that jurisdiction over declaratory judgment actions should be determined on the basis of an underlying action for damages or injunction rather

\% 29 U.S.C. $\S \S 1001-1461$ (1982).

${ }^{97} 103 \mathrm{~S}$. Ct. at 2845.

Id.

Id.

${ }^{100}$ See id. The Court noted that "[f]or better or worse, ... the present statutory scheme [of federal question jurisdiction] . . . has existed since 1887," id. at 2847 (emphasis added), and conceded that "[t]he [well-pleaded complaint] rule . . . may produce awkward results, especially in cases in which neither the obligation created by state law nor the defendant's factual failure to comply are in dispute, and both parties agree that the only question for decision is raised by a federal preemption defense," id. at 2848 (emphasis added).

${ }^{101}$ Id. at 2845-48.

${ }^{102} 339$ U.S. 667 (1950). 
than on the complaint for declaratory relief. ${ }^{103}$ The Court then held that the well-pleaded complaint rule precluded federal jurisdiction because the underlying cause of action-the Board's attachment claim-arose under state law. ${ }^{104}$

Although the Court might have concluded its opinion at this point, it went on to respond at some length to the Trust's argument that removal was proper under Avco Corp. v. Aero Lodge No. $735,^{105}$ which had tacitly approved preemption removal. ${ }^{106}$ The Franchise Tax Board Court recognized that, while a plaintiff is normally the master of his complaint, "it is an independent corollary of the well-pleaded complaint rule that a plaintiff may not defeat removal by omitting to plead necessary federal questions in a complaint."107 The Court interpreted Avco as "stand[ing] for the proposition that if a federal cause of action completely preempts a state cause of action any complaint that comes within the scope of the federal cause of action necessarily 'arises under' federal law."108 The Court concluded, however, that the Trust's reliance on Avco was misplaced. First, the Court reasoned, "Congress did not intend to preempt entirely every state cause of action relating to [ERISA] plans."109 Moreover, "[u]nlike the contract rights at issue in Avco, the State's right to enforce its tax levies [was] not of central concern to [ERISA]."110 Finally, ERISA did not provide the state with a superseding cause of action replacing its state-law claims, as was the case in Avco. ${ }^{111}$ This reasoning applied to the Board's declaratory judgment action as well as its attachment claim. ${ }^{112}$

While Franchise Tax Board thus made clear that in some text.

${ }^{108}$ For a discussion of the Skelly Oil rule, see supra notes $41-45$ and accompanying

$104103 \mathrm{~S}$. Ct. at 2849-53. There is some question as to whether the Court correctly applied the Skelly Oil principle. In unraveling the declaratory judgment action, the Court assumed that the hypothetical underlying suit was based on the state-law attachment claim. The Court ignored the possibility that the Trust might have paid the tax and then sued for a refund, see Cal Rev. \& TAX. CoDE $\S 26102$ (West 1979), claiming a federally created exemption from the tax. Had this occurred, there would in fact have been original federal jurisdiction.

108390 U.S. 557 (1968).

${ }^{106}$ See supra notes 7, 60-64 and accompanying text.

$107103 \mathrm{~S}$. Ct. at 2853.

${ }^{108}$ Id. at 2854. Until the Franchise Tax Board Court explained Avco, it was unclear whether that case could in fact be interpreted as approving preemption removal. See supra notes 60-64 and accompanying text.

${ }^{109} \mathrm{Id}$. at 2855.

110 Id.

111 Id.

112 Id. 
cases preemption removal was proper, the Court did not expressly resolve the underlying uncertainty as to the proper interpretation of the well-pleaded complaint rule, nor did it give much guidance for the difficult task of distinguishing between cases where preemption is merely a defense and those where preemption removal is consistent with the well-pleaded complaint rule. As a result, the status of the artful pleading doctrine and the superseding cause of action requirement remains unclear. Nonetheless, an analysis of the Court's treatment of the preemption removal problem yields insights into all three of these questions.

\section{A. Franchise Tax Board and the Well-Pleaded Complaint Rule}

Although the Court in Franchise Tax Board did not directly address the ambiguity in the interpretation of the well-pleaded complaint rule, the decision clearly proceeds from the assumption that the focus of the inquiry under the well-pleaded complaint rule is the actual nature of the underlying cause of action and not merely the language of the plaintiff's complaint. ${ }^{113}$ Indeed, the Court found it to be "an independent corollary of the well-pleaded complaint rule that a plaintiff may not defeat removal by omitting to plead necessary federal questions in a complaint."114 This emphasis on the cause of action is repeated throughout Franchise Tax Board. ${ }^{115}$ The Court carefully distinguished cases in which preemption is merely a defense from those in which preemption

11 See supra notes 49-57 and accompanying text. In fact, although the Franchise Tax Board Court quoted extensively from Gully, see $103 \mathrm{~S}$. Ct. at 2847-48, Justice Cardozo's famous statement that the federal question "must be disclosed upon the face of the complaint, unaided by the answer or by the petition for removal," 299 U.S. at 113, was conspicuously omitted. The only similar language cited by the Court, quoted from Taylor v. Anderson, 234 U.S. 74 (1914), does not expressly preclude matters raised in the answer or petition for removal: " 'Federal jurisdiction] must be determined from what necessarily appears in the plaintiff's statement of his own claim in the bill or declaration, unaided by anything alleged in anticipation of avoidance of defenses which it is thought the defendant may interpose." " $103 \mathrm{~S}$. Ct. at 2846 (quoting Taylor v. Anderson, 234 U.S. at 75-76).

$114103 \mathrm{~S}$. Ct. at 2853 . Although this language appears to reflect the concerns underlying the artful pleading doctrine, the court's failure explicitly to phrase its conclusion in such terms is conspicuous. See infra notes 123-26 and accompanying text (discussing the implications of Franchise Tax Board on the artful pleading doctrine). The quoted language illustrates the closeness of the relation between the notion of artful pleading and the underlying basis for allowing removal, namely, that the cause of action itself is federal. See supra note 94 and accompanying text.

115 For example, the Court formulates the rule of Avco as follows: "if a federal cause of action completely preempts a state cause of action any complaint that comes within the scope of the federal cause of action necessarily 'arises under' federal law." Franchise Tax Board, $103 \mathrm{~S}$. Ct. at 2854 (emphasis added); see supra notes 60-64 and accompanying text. 
affects the plaintiff's cause of action. ${ }^{116}$ Moreover, the extension of the Skelly Oil principle of looking to the underlying cause of action of declaratory judgments also suggests that the proper focus of the well-pleaded complaint rule is on the cause of action. ${ }^{117}$

The underlying difference between the Franchise Tax Board and Gully v. First National Bank ${ }^{118}$ interpretations of the wellpleaded complaint rule lies in their treatment of the notion that the plaintiff is master of his own complaint. Under Gully, this notion is absorbed into and becomes part of the well-pleaded complaint rule. ${ }^{119}$ Under Franchise Tax Board, the notion that the plaintiff is master of his complaint is treated as analytically separate from the well-pleaded complaint rule. ${ }^{120}$ In most situations, the two views of the well-pleaded complaint rule produce the same result, because the plaintiff's cause of action is ordinarily just what the complaint states it to be. Thus, the incorporation into the wellpleaded complaint rule of the notion that the plaintiff is master of his complaint is normally harmless. The Court in Franchise Tax Board concluded, however, that, in some instances, the "preemptive force of [federal law] is so powerful as to displace entirely any state cause of action," so that in such cases the plaintiff's right to

$118103 \mathrm{~S}$. Ct. at 2848 \& $\mathrm{n} .11$ (citing with approval cases denying removal based on preemption defenses), $2848 \mathrm{n} .12$ ("Note, however, that a claim of federal preemption does not always arise as a defense to a coercive action.").

${ }^{117}$ See supra notes 40-43 and accompanying text.

य28 299 U.S. 109 (1936).

110 For a discussion of the Gully rule, see supra notes 28-34 and accompanying text. Gully never expressly asserts the point, but this absorption is precisely what Gully holds. Cardozo engrafts the plaintiff's mastery of his complaint onto the well-pleaded complaint rule in order to simplify the task of the courts called upon to apply the rule. See Gully, 299 U.S. at 113. Although his intention is laudable, Cardozo's analysis is incorrect insofar as inclusion of the plaintiff's control of his complaint was later taken to be an ironclad requirement of the well-pleaded complaint rule. The two concepts-the well-pleaded complaint rule and the plaintiff's mastery of the complaint-are analytically distinct and serve different purposes. Franchise Tax Board thus abandons the plaintiff's mastery of his complaint as an accretion to the well-pleaded complaint rule where the purposes of the rule-determining whether a claim is actually federal-compel the Court to do so. See infra notes 120-23 and accompanying text.

$120103 \mathrm{~S}$. Ct. at 2853 (although party bringing suit is master to decide what law he will rely on, "it is an independent corollary of the well-pleaded complaint rule that a plaintiff may not defeat removal by omitting to plead necessary federal questions" (emphasis added)). See supra note 119.

Although no case has attributed the shift from the Gully construction of the wellpleaded complaint rule to that reflected in Franchise Tax Board to the laxity in modern pleading rules, the nature of pleadings today almost certainly makes many of the administrative advantages sought by Cardozo in formulating the Gully construction, see supra notes 60-64 and accompanying text, impossible to achieve. 
be master of his own complaint must yield. ${ }^{121}$

The Franchise Tax Board view of the well-pleaded complaint rule provides a better method for applying the rule. While applying the well-pleaded complaint rule certainly requires some concern for administrative convenience, administrability does not explain why the courts disregard allegations in a complaint that anticipate a defense, or, more importantly, why the courts recharacterize declaratory judgment actions to identify a hypothetical underlying cause of action. Departures such as these result from a recognition that the purposes of the well-pleaded complaint rule may require the Court to look past the plaintiff's complaint. The rule requires ascertaining whether the cause of action that constitutes the underlying dispute is actually federal. If it is a federal cause of action, there is original federal question jurisdiction. Thus, even if one assumes that to promote administrative convenience the courts normally accept the Gully construction of the well-pleaded complaint rule, one can understand why the same courts also disregard this concern when the more fundamental purposes of the well-pleaded complaint rule are served by doing so. ${ }^{122}$

221 $103 \mathrm{~S}$. Ct. at 2853 . The Court reached a similar conclusion in Avco. See supra notes 60-64 and accompanying text.

${ }_{123}$ An important aspect of the Franchise Tax Board and Avco approach which the Court has never addressed is precisely why the important federal policy of preemption requires that the plaintiff's complaint be recharacterized as federal so that removal is allowed. It would be possible to serve the federal interest by letting the plaintiff assert only his statelaw claims, thereby essentially "waiving" any federal claims. If the plaintiff is allowed to rely solely on state law, and that law has been completely preempted, then the plaintiff should lose on his state-law claim in state court. If the state court is hostile to federal law and nonetheless allows recovery, there is appellate review of the "complete preemption" claim in the Supreme Court. See 28 U.S.C. $\$ 1257(2)$ (1982). The procedural protection of federal rights under such an approach would not differ from that accorded any party asserting a federal defense to a state law claim, and it is unfortunate that the Supreme Court did not explain in Franchise Tax Board its basis for treating preemption differently from other, similar claims.

One basis for doing so is technical. It is not the well-pleaded complaint rule that is changed by the force of the argument from complete preemption. Rather, it is merely the link between that rule and the notion that the plaintiff is master of his own complaint that is severed. It is this latter interest that must give way to the preemptive force of federal law, and, once that occurs, the courts' examination of the underlying cause of action can be unrestrained, and the courts can recharacterize the action as arising under federal law, whereupon standard application of the well-pleaded complaint rule will then find jurisdiction proper.

The answer that complete preemption makes the cause of action federal, however, while technically correct, is still not completely satisfying. Why should the court presume that plaintiff wants to assert any federal rights rather than to waive them? And if, indeed, the plaintiff intends to waive his federal rights, the court has authority to decide neither the case upon removal nor even the preemption issue. A more thorough analysis than that given by the Court in Avco or Franchise Tax Board is needed to explain what purposes of federal 


\section{B. Franchise Tax Board and the Artful Pleading Doctrine}

Although the statement in Franchise Tax Board that "a plaintiff may not defeat removal by omitting to plead necessary federal questions"123 evokes concerns similar to those which underlie the artful pleading doctrine, ${ }^{124}$ the Court did not expressly refer to the doctrine in discussing preemption removal. This omission is curious given the prior dominance of the doctrine in the analysis of preemption removal in the lower courts, ${ }^{126}$ especially in light of the Court's recent approval of the doctrine in Federated Department Stores, Inc. v. Moitie. ${ }^{126}$ Against this backdrop, the Franchise Tax

law or jurisdiction are served by allowing the court this liberty.

Several reasons may be advanced in support of the result. First, the distinction between ordinary preemption and the "complete preemption" of which the Franchise Tax Board Court speaks highlights a peculiarly powerful federal interest in the operative substantive law. See infra notes 143-48 and accompanying text. Congress has spoken more forcefully when it preempts an entire field of law and has indicated its desire that only federal law remain. This is the federal interest that compels the Court to look beyond the face of the complaint; the necessary jurisdictional consequence is that the cause of action is made federal, permitting removal.

Second, there is force to the argument that when Congress has acted to preempt an entire field, reliance on appeal to the Supreme Court under 28 U.S.C. $\$ 1257$ (1982) to vindicate the federal concerns is inadequate. Congress's intent was to displace state-law causes of action entirely. Because of the time or expense involved or for any of a number of reasons, not all appeals will be pursued. The option to remove enhances the likelihood that this federal interest in preempting the field will not be subverted by hostile state courts. Finally, it must be noted that the plaintiff does not lose his right to waive federal claims. He may still waive these claims and suffer a dismissal. All the plaintiff loses is the chance to litigate state-law claims that no longer properly have the force of law, in the hope that the fact of preemption will not be raised.

$123103 \mathrm{~S}$. Ct. at 2853.

124 See supra notes 85-89 and accompanying text.

${ }^{123}$ See supra note 89 and accompanying text.

${ }^{126} 452$ U.S. 394 (1981). The plaintiffs in Moitie had refiled actions in state court which previously had been dismissed on the merits in federal court. Id. at 395-96. Before considering whether the later actions were barred by res judicata, the Court addressed the threshold question of whether the district court below had properly allowed the action to be removed from state court. Id. at 397 n.2. Agreeing that "at least some of the claims had a sufficient federal character to support removal," $i d$. at $397 \mathrm{n} .2$, the Court held that it would "not permit plaintiff to use artful pleading to close off defendant's right to a federal forum," id. (quoting C. WriGHT, A. Miller \& E. Cooper, supra note 85, § 3722, at 564-66). The Court accepted the factual finding below of artful pleading. Id. Moitie is a fine example of the confused results produced by the focus on plaintiff's motive in the artful pleading doctrine. The Court permits removal even though the plaintiff alleges state law exclusively, obviously confusing the importance that res judicata may have as a federal policy with the force of preemption as a federal policy. See supra notes 113-22 and accompanying text. Res judicata does not provide sufficient warrant for the Court to look past the face of the complaint. Preemption, expressing congressional as well as constitutional concerns, raises issues beyond the mere considerations of judicial economy underlying claim preclusion. By focusing on the intent of the plaintiffs, the Court seems to have missed this fact. In Moitie, a preferable disposition would have been to remand to the state court to dismiss on the res judicata 
Board Court's failure to invoke artful pleading might be interpreted as evidencing a retreat from its prior acceptance of the doctrine.

Indeed, since Franchise Tax Board separates the plaintiff's mastery of his complaint from the well-pleaded complaint rule, ${ }^{127}$ an exception to the well-pleaded complaint rule such as the artful pleading doctrine is no longer required. Any focus on the plaintiff's motive is misplaced: it is not the plaintiff's bad motive which renders a case removable but rather the effect of preemption on his cause of action. In general, where both state and federal law provide a cause of action, the plaintiff is free to ignore the federal law and rely solely on state law even if his only reason for doing so is to avoid federal jurisdiction. ${ }^{128}$ After Franchise Tax Board, however, where federal law has "completely preempted" the state law cause of action, it is proper to recharacterize the action as one that actually arises under federal law, despite the plaintiff's usual mastery over his complaint. ${ }^{29}$ It is not the motive of defeating federal jurisdiction that justifies removal. Whether or not the plaintiff's state law cause has been preempted, his motive for relying on state law is the same. The effect of "complete preemption" justifies recharacterizing the complaint as federal regardless of the plaintiff's motives. ${ }^{130}$

The artful pleading doctrine's focus on the plaintiff's motive diverts attention from the proper analysis of the relationship between preemption and the plaintiff's cause of action. ${ }^{131}$ For example, some courts have suggested that if the plaintiff is simply negligent, removal might be proper on the basis of a preemption defense. ${ }^{132}$ In other cases, even where a federal cause of action has completely preempted a state law cause of action removal has been denied on the ground that the plaintiff had relied on state law in good faith. ${ }^{133}$ Such results do not fit easily with the analysis of

defense. See infra notes 127-33 and accompanying text.

127 See supra notes 119-21 and accompanying text.

${ }^{128}$ See, e.g., Franchise Tax Board, 103 S. Ct. at 2853; The Fair v. Kohler Die \& Specialty Co., 228 U.S. 22, 25 (1913); Fay v. American Cystoscope Makers, Inc., 98 F. Supp. 278, 280-81 (S.D.N.Y. 1951).

${ }_{129}$ See Franchise Tax Board, 103 S. Ct. at 2854; supra note 122.

130 See supra note 122.

131 For an example of the distorted results produced by the artful pleading doctrine, see Federated Dep't Stores, Inc. v. Moitie, 452 U.S. 394 (1981), discussed supra note 126.

${ }^{132}$ See, e.g, Eure v. NVF Co., 481 F. Supp. 639, 644 (E.D.N.C. 1979) (where there is an obvious conflict between state and federal law, the plaintiff is on notice and removal is proper).

${ }^{133}$ See cases cited supra notes 85-88. 
Franchise Tax Board that finds justification for removal in the necessarily federal nature of the plaintiff's cause of action. Although careful application of the artful pleading doctrine might yield correct results, the doctrine is not essential to the rationale of preemption removal advanced in Franchise Tax Board, and should be abandoned.

\section{Franchise Tax Board and the Superseding Cause of Action Requirement}

Franchise Tax Board is also unclear as to whether a superseding federal cause of action is necessary for preemption removal. The Court's statement of the Avco principle does suggest that the presence of a superseding federal cause is an important element in allowing removal: removal is proper where "a federal cause of action completely preempts a state cause of action . . ."134 And it does appear somewhat illogical to say that the plaintiff's cause of action arises under federal law when federal law grants him no cause of action. Yet, if the existence of a superseding federal cause were a requirement for removal, the absence of such a cause under ERISA should have been dispositive in Franchise Tax Board, and the Court's ensuing discussion of other factors would have been unnecessary. Moreover, in contrast to lower court cases relying on the presence of a superseding cause to limit preemption removal, ${ }^{135}$ the Supreme Court did not refer to the presence of a superseding cause as a requirement; ${ }^{136}$ the absence of a superseding cause of action under ERISA was but one factor used by the Franchise Tax Board Court to distinguish Avco. ${ }^{137}$

Franchise Tax Board thus leaves open the possibility that preemption removal is in some instances proper despite the absence of a superseding federal cause of action. The question then becomes whether such removal is consistent with the Franchise Tax Board view of the well-pleaded complaint rule that requires that a federal question must be presented by the plaintiff's cause of action. If federal law merely preempts state law without substituting a federal cause of action, the only result of the preemption is that the plaintiff loses for failure to state a claim. In such cases preemption does indeed appear to be merely a defense. And, since

134103 S. Ct. at 2854.

195 See supra notes 90-94 and accompanying text.

${ }^{136} 103 \mathrm{~S}$. Ct. at 2854-55.

${ }^{137}$ The Court also made arguments from the language of the ERISA statute and the legislative history and general policies behind ERISA. See id. 
the Court in Franchise Tax Board was careful to point out that removal could not be predicated on an ordinary preemption defense, ${ }^{138}$ it would appear at first glance that a superseding cause of action is necessary.

The conclusion that the absence of a superseding federal cause of action necessarily means that the preemption claim is merely a defense, however, confuses the question of whether a plaintiff is entitled to recover under federal law with the question of whether the only body of law upon which the plaintiff could base his cause of action is federal. The difference between these two propositions can be illustrated by an analogy to the field of choice of law. ${ }^{139}$ Suppose a plaintiff from state $X$ seeks to recover for injuries arising from an accident which occured in state $Y$. State $X$ provides the plaintiff with a cause of action, but state $Y$ does not. The court may determine that the law of state $Y$ applies, but gives the plaintiff no right of recovery. ${ }^{140}$ Nonetheless, it is clear that the plaintiff's cause of action presents questions of state $Y$ law. In such a case it is certainly not illogical to say that the case arises under state $Y$ law, even though that law grants the plaintiff no rights. ${ }^{141}$ By analogy, it is possible to conceive of situations in which the existence of a cause of action must be tested under federal law, even though the federal law provides no superseding cause of action. Allowing removal in such cases is consistent with the Franchise Tax Board rationale of the well-pleaded complaint rule since the plaintiff's cause of action presents questions of federal law. Although the existence of a superseding cause of action may be relevant in

138 Id. at 2848 \& n.11.

199 See Billy Jack For Her, Inc. v. New York Coat Workers Union Local 1-35, 511 F. Supp. 1180 (S.D.N.Y. 1981), where the court analogized the preemption removal problem to a choice-of-law inquiry and rejected the requirement of a superseding cause of action:

The Court finds nothing "illogical" in holding that preemption always creates "arising under" jurisdiction, even in a case where the preemptive federal law provides the plaintiff with no right to relief. The reports are certainly well stocked with cases where the plaintiff maintained an action under federal law only to discover to its chagrin that federal law afforded no remedy. Surely there is nothing illogical in describing such cases as having arisen under federal law.

Id. at 1187. Although the Billy Jack court's rationale for rejecting the superseding cause of action requirement is persuasive, the problem of distinguishing preemption defenses from cases where removal is proper remains. One possible solution is offered infra notes 142-57 and accompanying text.

${ }^{140}$ See, e.g., Offshore Rental Co. v. Continental Oil Co., 22 Cal. 3d 157, 148 Cal. Rptr. 867, 583 P.2d 721 (1978) (action by California corporation seeking damages for injury in Louisiana to "key employee" is controlled by Louisiana law, which, unlike California law, provides no such cause of action).

1 'See supra note 139. 
determining whether the plaintiff's cause of action is within the field of law preempted by federal law, ${ }^{142}$ it should not be the primary focus in distinguishing cases in which preemption is merely a defense from cases where preemption removal is proper.

Thus the existence or nonexistence of a superseding federal cause of action does not form a dispositive basis for distinguishing preemption defenses from cases where removal is proper; yet the distinction must still be made. The appropriate, though more difficult, inquiry is whether any cause of action which could be presented by the plaintiff's complaint must be created by federal law. A two-part test for making this determination is suggested by the manner in which the Franchise Tax Board Court distinguished the case before it from that presented in $A v c o$, where removal was allowed. ${ }^{143}$

The first part of the test is an inquiry into the nature of the preemption involved. Under traditional preemption doctrine, if federal law is said to occupy an entire field of regulation ("field preemption"), it will preempt any state law in that field, whether or not the particular state law impairs the federal law's operation. ${ }^{144} \mathrm{~A}$ finding of field preemption is based upon congressional intent, generally express but sometimes inferred from the dominance of federal regulation in the particular field. ${ }^{145} \mathrm{~A}$ second kind of preemption occurs, however, when a state statute as construed conflicts with, or impairs the operation of, a federal law, in which case the supremacy clause of the Constitution ${ }^{146}$ requires the state law to yield ("conflict preemption"). ${ }^{147}$ The distinction between these two forms of preemption is often elusive. Conflict preemption is only that minimal preemption necessary to insure the supremacy of federal law by preventing state laws from impairing the federal law's operation. Field preemption, on the other hand,

${ }^{142}$ See infra note 157 and accompanying text.

${ }^{143}$ See Franchise Tax Board, $103 \mathrm{~S}$. Ct. at 2853-55.

144 See, e.g., Florida Lime \& Avocado Growers, Inc. v. Paul, 373 U.S. 132 (1963); Campbell v. Hussey, 368 U.S. 297 (1961); Pennsylvania v. Nelson, 350 U.S. 497 (1956); Rice v. Sante Fe Elevator Corp., 331 U.S. 218 (1947). See generally Note, The Preemption Doctrine: Shifting Perspectives on Federalism and the Burger Court, 75 CoLUm. L. REv. 623 (1975) (discussing expansion of preemption under the Warren Court, and the subsequent decline under the Burger Court); Comment, $A$ Conceptual Refinement of the Doctrine of Federal Preemption, 22 J. PUB. L. 391 (1973) (distinguishing between preemption and federal supremacy and between preemption and systematic prohibition of state power).

${ }^{145}$ See authorities cited supra note 144.

148 U.S. Const. art. VI, \& 2.

167 See, e.g., Perez v. Campbell, 402 U.S. 637 (1971); Houston v. Moore, 18 U.S. (5 Wheat.) 1 (1820). 
casts a broader net when Congress decides that an area of law must be exclusively federal.

In distinguishing Avco, the Court in Franchise Tax Board noted that "Congress did not intend to preempt entirely every state cause of action relating to [ERISA] plans."148 This language suggests that ERISA, unlike section 301 of the LMRA at issue in $A v c o$, does not occupy the field, and that any preemption involved in the Franchise Tax Board case was conflict preemption.

Although few of the courts that have considered preemption removal have expressly adverted to the distinction between field and conflict preemption, the language of courts approving preemption removal reveals that field preemption was usually involved.149 In addition, the differences between field and conflict preemption support the conclusion that removal should be allowed only where field preemption is involved. Conflict preemption can only arise in defense to a state law claim, since conflict preemption requires construction of both state and federal law in order to determine if they are compatible; preemption occurs only because the plaintiff's right to recover under state law as properly construed conflicts with federal law. ${ }^{150} \mathrm{By}$ contrast, if federal law occupies the field, all state law in that field is displaced whether or not it impairs federal law, ${ }^{151}$ and any cause of action within that field must be tested under federal law. Conflict preemption requires that the court closely examine the nature and operation of the state law in order to determine the extent to which the operation of federal laws may be impaired-something comity urges be left to the states in the first instance with federal court review on appeal. ${ }^{152}$ Field preemption, on the other hand, requires only that the federal court examine the general subject matter of the state law in order to ascer-

148103 S. Ct. at 2855.

149 See, e.g., First Fed. Sav. \& Loan Ass'n v. First Fed. Sav. \& Loan Ass'n, 446 F. Supp. 210, 212 (N.D. Ala. 1978) ("It seems clear that there has been federal preemption in the field . . . ."); Rettig v. Arlington Heights Fed. Sav. \& Loan Ass'n, 405 F. Supp. 819, 823 (N.D. Ill. 1975) ("[C]ourts have consistently recognized the congressional intent to have federal law govern the regulation and supervision of federal associations."). But cf. Gunter v. Ago Int'l B.V., 533 F. Supp. 86, 88-90 (N.D. Fla. 1981) (approving removal in securities law context because of conflict between state and federal law); Eure v. NVF Co., 481 F. Supp. 639, 644 (E.D.N.C. 1979) (rejecting preemption removal generally but indicating that artful pleading would be found where state and federal law conflict directly).

150 See supra note 147 and accompanying text.

${ }^{181}$ See supra notes $144-45$ and accompanying text.

${ }^{162}$ Cf. Louisiana Power \& Light Co. v. City of Thibodaux, 360 U.S. 25 (1959) (approving abstention where an area of peculiar interest to state is involved); Railroad Comm'n v. Pullman Co., 312 U.S. 496, 500 (1941) (abstain where state law is unclear to let state court decide and thus "avoid[] needless friction with state policies"). 
tain if it regulates activity that is "arguably subject" to the federal regulation. ${ }^{153}$

More importantly, the nature of the federal policy interest involved in field preemption is arguably greater than that involved in conflict preemption. The occupation of an entire field of law to the exclusion of any state law implies a special concern on the part of Congress for the need for uniform federal regulation in the field above and beyond the concern emanating solely out of the supremacy clause. That this is the expression of a stronger federal interest than that expressed by ordinary conflict preemption is evidenced by the presumption of validity accorded state law in cases of conflict preemption. ${ }^{154}$

If the federal law in question has in fact occupied the field, the second step in considering whether removal is proper is to determine whether the plaintiff's cause of action is within that field. This factor also figured in the Court's denial of removal in Franchise Tax Board. Assuming for purposes of this portion of its discussion that federal law had occupied the field of ERISA trusts, the Court noted that the scope of the occupied field was nonetheless limited: the statute in question did not "purport to reach every question relating to plans covered by ERISA."15s Thus, in Franchise Tax Board, unlike in Avco, the plaintiff's state-law cause of action to recover taxes was not "of central concern to the federal statute,"156 and the cause of action could not be within a field of law preempted by ERISA. It is in this context that the Court's inquiry into the existence of a superseding cause of ac$\operatorname{tion}^{157}$ is relevant. If there is a superseding cause that concerns the same subject-matter as the state cause of action alleged in the complaint, then the state law cause of action certainly touches on areas of central concern to the federal law, and is within the preempted field.

\section{CoNCLUSION}

This comment has attempted to provide a systematic analysis of the preemption removal problem. The halting emergence of the preemption removal problem, and the disarray it evoked in the

${ }^{163}$ San Diego Bldg. Trades Council v. Garmon, 359 U.S. 236, 245 (1959) (finding California labor laws preempted by federal labor law).

${ }^{164}$ See $103 \mathrm{~S}$. Ct. at 2855.

${ }^{165}$ Id. at 2854.

${ }^{168}$ Id. at 2855.

${ }^{157}$ See id. 
lower courts, was exacerbated by underlying uncertainties regarding the proper application of the well-pleaded complaint rule. In Franchise Tax Board, the Supreme Court recognized preemption removal in certain cases, and appears to have decided the appropriate general method of applying the well-pleaded complaint rule. Examination of Franchise Tax Board suggests that the decision is inconsistent with a construction of the well-pleaded complaint rule that strictly limits a court's inquiry to the language of the plaintiff's complaint. Rather, at least in the preemption context, Franchise Tax Board calls for a construction of the rule that requires an examination of the true nature of the plaintiff's underlying cause of action. In light of this interpretation of Franchise Tax Board, the comment argues that the artful pleading doctrine cannot be said to reflect accurately the principles underlying the Supreme Court's recognition of preemption removal. Finally, the comment suggests that a superseding cause of action, though a significant factor, is not always necessary for preemption removal, and proposes a two-step test for determining whether removal is proper in a given case: first, whether the federal law at issue has preempted an entire field of state law; and second, whether the state law upon which the plaintiff bases his claim is within that field.

Richard E. Levy 